\title{
PERAN KEPALA SMK NEGERI DI KOTA YOGYAKARTA BERDASARKAN PERSEPSI GURU
}

\author{
Vivianti \\ Universitas Teknologi Yogyakarta \\ vivian.apriyadi@gmail.com \\ Samsul Hadi \\ Universitas Negeri Yogyakarta \\ samsul.hd@gmail.com
}

\begin{abstract}
Abstrak
Penelitian ini bertujuan untuk mengetahui: (1) model konstruk peran kepala SMK yang ideal, yakni mencakup dimensi dan indikator peran kepala SMK dan (2) kondisi riil peran kepala SMK di Kota Yogyakarta. Penelitian ini merupakan penelitian ex-post facto, yang dilaksanakan di 8 SMK Negeri di Kota Yogyakarta. Teknik pengambilan sampel dengan proportionale random sampling. Sampel yang digunakan sebanyak 200 sampel. Teknik analisis data yang digunakan adalah Structural Equation Modelling (SEM) dengan pendekatan analisis faktor konfirmatori (Confirmatory Factor Analisys, CFA). Hasil penelitian menunjukkan bahwa: (1) Model konstruk peran kepala sekolah memiliki 2 dimensi, yaitu dimensi kepemimpinan dan dimensi manajerial. Kepemimpinan mempunyai 5 indikator, yaitu (a) kecakapan pribadi, (b) kecakapan relasional, (c) kecakapan profesional, (d) kecakapan berorganisasi, dan (e) kecakapan wirausaha. Manajerial mempunyai 4 indikator, yaitu (a) perencanaan, (b) pengorganisasian, (c) penggerakan, dan (d) pengendalian; (2) Kondisi riil peran kepala sekolah hampir sesuai dengan kondisi idealnya, ditunjukkan dengan mean kondisi riil yang sedikit lebih rendah dari mean kondisi ideal. Secara rinci kondisi riil peran kepala sekolah berdasar persepsi guru menunjukkan bahwa 28,36\% guru memberikan nilai sangat tinggi, 59,20\% guru memberikan nilai tinggi, 11,44\% memberikan nilai sedang, 1,00\% memberikan nilai rendah, dan $0 \%$ memberikan nilai sangat rendah.
\end{abstract}

Kata kunci: peran, kepemimpinan, manajerial, SEM, CFA

\section{THE ROLE OF PRINCIPALS OF VOCATIONAL HIGH SCHOOLS IN YOGYAKARTA BASED ON TEACHER'S PERCEPTIONS}

Abstract

This study aimed to determine: (1) a construct model of the role of ideal principal in the vocational high school, which includes the dimensions and indicators of the role of the principal of vocational and (2) the real condition of the role of the principal of vocational schools in the city of Yogyakarta. This study was an ex-post facto implemented in 8 vocational high schools in the city of Yogyakarta. The population of this study was 983 teachers from 8 vocational schools. The sampling technique used was proportional random sampling. The samples were then distributed to 200 samples. The data analysis technique used was Structural Equation Modeling (SEM) with confirmatory factor analysis approach (Confirmatory Factor Analisys, CFA). The results of this research show that: (1) the construct model of the principal's role has two dimensions, the leadership dimensions and managerial dimensions. The leadership has 5 indicators, namely (a) the personal capabilities, (b) relational capabilities, (c) professional capabilities, (d) organizational capabilities, and (e) the entrepreneur capabilities. The managerial has four indicators, namely (a) planning, (b) organizing, (c) actuating, and (d) controlling; (2) the real condition of the role of the principal is almost the same as the ideal conditions. It is indicated by the mean of real conditions which is a little bit lower than the mean of ideal conditions. In details, the real condition of the principal's role based on the perception of teachers shows that $28.36 \%$ of teachers give very high value, $59.20 \%$ of teachers give high value, $11.44 \%$ of them give moderate value, $1.00 \%$ give a low value and $0 \%$ of them give a very low value.

Keywords: role, leadership, managerial, SEM, CFA 


\section{PENDAHULUAN}

Pendidikan menengah kejuruan adalah pendidikan pada jenjang pendidikan menengah yang mengutamakan pengembangan kemampuan siswa untuk melaksanakan jenis pekerjaan tertentu. Pendidikan menengah kejuruan mengutamakan penyiapan siswa untuk memasuki lapangan kerja serta mengembangkan sikap profesional. Sesuai dengan bentuknya, sekolah menengah kejuruan menyelenggarakan program-program pendidikan yang disesuaikan dengan jenisjenis lapangan kerja (Peraturan Pemerintah Nomor 29, 1990).

Peraturan Pemerintah Nomor 17 Tahun 2010 tentang Pengelolaan dan Penyelenggaraan Pendidikan (2010) menyebutkan bahwa pendidikan menengah kejuruan berfungsi untuk (a) meningkatkan, menghayati, dan mengamalkan nilai-nilai keimanan, akhlak mulia, dan kepribadian luhur; (b) meningkatkan, menghayati, dan mengamalkan nilai-nilai kebangsaan dan cinta tanah air; (c) membekali peserta didik dengan kemampuan ilmu pengetahuan dan teknologi serta kecakapan kejuruan para profesi sesuai dengan kebutuhan masyarakat; (d) meningkatkan kepekaan dan kemampuan mengapresiasi serta mengekspresikan keindahan, kehalusan, dan harmoni; (e) menyalurkan bakat dan kemampuan di bidang olahraga, baik untuk kesehatan dan kebugaran jasmani maupun prestasi; dan (f) meningkatkan kesiapan fisik dan mental untuk hidup mandiri di masyarakat dan/atau melanjutkan pendidikan ke jenjang pendidikan tinggi.

Ketercapaian tujuan pendidikan tentunya sangat berkaitan dengan keberhasilan seorang kepala sekolah dalam menjalankan peranannya karena kepala sekolah merupakan pemimpin dalam suatu sekolah. Faktor-faktor yang mempengaruhi kinerja sekolah menurut adalah: (a) kepemimpinan sekolah yang kuat (strong principal leadership); (b) suasana sekolah (climate) (c) lingkungan yang tertata dengan rapi (orderly environment); (d) harapan tinggi pada siswa untuk berprestasi (expectation for student achievement); (5) penekanan pendidikan pada ketrampilan dasar (emphasis on basic skills); dan sistem evaluasi yang sistematis dan berkesinambungan (frequent and systematic evalution of students) (Edmonds, 1997, p.106).

Kepemimpinan kepala sekolah adalah kunci untuk lingkungan sekolah yang baik dan mencapai pengajaran serta pembelajaran yang berkualitas. Kepemimpinan kepala sekolah yang baik dibutuhkan oleh para guru. Keputusan kepala sekolah mempengaruhi sekolah yang dipimpin (Rice, 2010, p.1; Wahlstrom \& Louis, 2008, p.458). Kepala sekolah memainkan peran penting dalam upaya meningkatkan standar pengajaran, pembelajaran siswa, serta prestasi siswa (Day dan Harris, 1999, p.6). Kepala sekolah merupakan orang yang memberdayakan orang lain, mendorong kreativitas dan fleksibilitas, meningkatkan perencanaan kolaboratif dan berbagi pengambilan keputusan dalam upaya untuk mengembangkan kepercayaan di seluruh lingkungan sekolah, dan memanfaatkan sifatsifat ini sebagai katalis untuk restrukturisasi dan reformasi sekolah sukses (Beyer \& RuhlSmith, 1998, p.116). Tanggung jawab dan peran penting tesebut mengharuskan kepala sekolah melaksanakan kewajiban mereka secara bertanggung jawab dan hati-hati. Kesalahan kepala sekolah dalam melaksanakan kewajiban dapat menyebabkan ketidakpuasan di kalangan guru, manajemen sekolah yang buruk, dan hasil belajar siswa yang buruk (Barnett \& McCormick, 2004, p.406).

Peran kepala sekolah begitu penting bagi peningkatan mutu pendidikan. Namun, sayangnya peran kepala sekolah di Indonesia ini masih rendah. Seperti yang diliput oleh Napitupulu dalam surat kabar Kompas (2012) bahwa kepala sekolah di jenjang TK sampai SMA/SMK di berbagai daerah sejak otonomi daerah dinilai memprihatinkan. Kenyataan ini akibat penunjukkan kepala sekolah yang lebih didasarkan pada kepentingan politik terkait dengan dukungan pada pemilihan kepala daerah dibandingkan profesionalisme sebagai pemimpin sekolah. Lebih lanjut Presidium Federasi Serikat Guru Indonesia (FSGI), Guntur Ismail mengatakan, Kementerian Pendidikan dan Kebudayaan harus melakukan pembinaan dan kontrol atas kinerja para kepala sekolah (Arikuntono, 2012). 
Seperti diliput dalam website resmi Kementerian Pendidikan dan Kebudayaan Republik Indonesia (2013), kesenjangan lain mengenai kepemimpinan kepala sekolah di Indonesia juga diungkapkan dalam penelitian Analytical and Capacity Development Partnership (ACDP). Penelitian ini merupakan hasil kerjasama pemerintah Indonesia, Australia, Eropa, dan Asian Development Bank (ADP). Hasil penelitian menunjukkan kepala sekolah di Indonesia memiliki kompetensi supervisi yang rendah. Hal tersebut menyebabkan penilaian dan peningkatan kualitas belajar mengajar tidak dapat akurat dilakukan karena kepala sekolah tidak melakukan pengawalan terhadap tugas harian guru.

Kepala sekolah atau pemimpin sekolah yangmenerapkan peran dan tugasnyaharus terus ditinjau guna melihat transparansi kepemimpinan di sekolah, karena kepemimpinan dapat memiliki dampak terhadap moral, motivasi, dan kepuasan kerja para guru (Evans, 2001, p.291). Berdasarkan pernyatan tersebut maka kepemimpinan Kepala Sekolah terbukti berdampak pada salah satu komponen sekolah yaitu Guru. Persepsi guru tentang bagaimana mereka dihargai dan didukung oleh kepala sekolah berpengaruh terhadap keputusan mereka untuk memotivasi siswa sehari-hari (Demir, 2008, pp.95-96). Oleh karena itu, persepsi guru merupakan salah satu alternatif cara pandang untuk menilai peran seorang kepala sekolah karena guru bekerja sama langsung dengan mereka (Demir, 2008, p. 99). Keberhasilan guru dan siswa adalah akibat langsung dari hubungan mereka dengan kepala sekolah mereka (Edgerson \& Kritsonis, 2006, p.4).

Yogyakarta hingga saat ini masih lekat dengan julukan kota pelajar. Potensi pendidikan di Yogyakarta tidak hanya diakui oleh masyarakat setempat, tetapi juga oleh masyarakat di seluruh Indonesia. Berdasarkan data pokok Direktorat Pembinaan Sekolah Menengah Kejuruan, Yogyakarta memiliki 8 SMK Negeri dan 7 SMK Swasta. Dalam sebuah artikel yang dimuat pada surat kabar Tempo (2013), Idhom mengungkapkan meski mendapat julukan kota pendidikan, pengaduan masyarakat ke Ombudsman Republik Indonesia
(ORI) Perwakilan DIY selama 2013 didominasi kasus buruknya pelayanan pendidikan.

Seperti diliput oleh Neni dalam Republika (2010) di Kota Yogyakarta terdapat berbagai kasus mengenai pelanggaran yang dilakukan sekolah di antaranya melakukan pungutan secara liar, memberlakukan pengadaan seragam secara paksa, menarik pungutan registrasi dan her registrasi, penyanderaan ijazah dan rapor, intimidasi terhadap siswa, dan penyimpangan RAPBS serta anggaran PPDB (Pendaftaran Peserta Didik Baru). Pada tingkat SMK, terdapat 4 SMK Negeri di Kota Yogyakarta yang dilaporkan ke Kejati DIY. Ancaman diberikan kepada sekolah selaku penangungjawab pelaksanaan pendidikan.

Hal lain yang masih menjadi permasalahan dalan dunia SMK adalah menyenai daya serap lulusan. Dari data 2012, lulusan SMA/SMK masih mendominasi pengangguran di Kota Yogyakarta (Sidik, 2013).

Pada situs resmi Pemerintah Kota Yogyakarta (2007), disebutkan bahwa sebagai upaya melakukan perbaikan, penyegaran kepemimpinan dan peningkatan kualitas pendidikan di kota Yogyakarta Pemkot Yogyakarta melakukan perombakan kepala sekolah di beberapa Sekolah menengah Atas (SMA) dan Sekolah Menengah Kejuruan (SMK). Namun, pada perombakan kepala SMK terdapat mutasi atau perpindahan dimana kepala SMK yang semula menjabat pada SMK yang notabene merupakan sekolah menengah teknik kemudian pindah ke SMK yang notabene merupakan sekolah menengah ekonomi atas, dan sebaliknya. Hal ini menjadikan tanda tanya mengenai peran kepala sekolah, baik dalam hal kompetensi ataupun strategi kepala sekolah dalam memajukan sekolah yang mana tentu akan berbeda.

Sesuai dengan teori mengenai keberhasilan sekolah di atas, tentunya berbagai permasalahan mengenai SMK ini sangat dipengaruhi oleh kepemimpinan kepala sekolah. Sampai saat ini belum ada penelitian lebih lanjut mengenai peran kepala SMK di Kota Yogyakarta, khususnya berdasarkan persepsi guru.

Penilaian peran kepala SMK berdasarkan pesepsi guru membutuhkan adanya instrumen untuk mengetahui model peran kepala SMK 
Tabel 1. Populasi dan Sampel Proporsional Setiap Sekolah

\begin{tabular}{|c|c|c|c|}
\hline No & Nama Sekolah & Populasi & Sampel \\
\hline 1 & SMK N 1 Yogyakarta & 61 & 12 \\
\hline 2 & SMK N 2 Yogyakarta & 239 & 49 \\
\hline 3 & SMK N 3 Yogyakarta & 185 & 38 \\
\hline 4 & SMK N 4 Yogyakarta & 147 & 30 \\
\hline 5 & SMK N 5 Yogyakarta & 116 & 24 \\
\hline 6 & SMK N 6 Yogyakarta & 106 & 22 \\
\hline 7 & SMK N 7 Yogyakarta & 71 & 14 \\
\hline 8 & SMTI & 58 & 12 \\
\hline \multicolumn{2}{|c|}{ Total } & 983 & 210 \\
\hline
\end{tabular}

yang ideal. Untuk menyusun instrumen yang baik, tentunya dibutuhkan kajian mengenai model dari peran kepala sekolah itu sendiri. Setelah diketahui model peran yang ideal, baru penilaian peran kepala sekolah berdasarkan persepsi guru dapat dilakukan.

\section{METODE PENELITIAN}

\section{Jenis Penelitian}

Penelitian ini merupakan penelitian expost facto menggunakan pendekatan kuantitatif.

\section{Waktu dan Tempat Penelitian}

Penelitian ini mengambil lokasi di SMK Negeri yang berada di Kota Yogyakarta, yaitu SMK Negeri 1 Yogyakarta, SMK Negeri 2 Yogyakarta, SMK Negeri 3 Yogyakarta, SMK Negeri 4 Yogyakarta, SMK Negeri 5 Yogyakarta, SMK Negeri 6 Yogyakarta, SMK Negeri 7 Yogyakarta, dan Sekolah Menengah Teknologi Industri(SMTI). Proses pengumpulan data dilakukan selama bulan Juni hingga November 2014.

\section{Target/Subjek Penelitian}

Populasi dalam penelitian ini adalah semua guru di 8 SMK Negeri di Kota Yogyakarta, yaitu SMK Negeri 1 Yogyakarta, SMK Negeri 2 Yogyakarta, SMK Negeri 3 Yogyakarta, SMK Negeri 4 Yogyakarta, SMK Negeri 5 Yogyakarta, SMK Negeri 6 Yogyakarta, SMK Negeri 7 Yogyakarta, dan Sekolah Menengah Teknologi Industri (SMTI). Jumlah populasi guru di 8 SMK sejumlah 983 guru.
Jenis pengambilan sampel yang digunakan dalam penelitian ini adalah probability sampling dengan teknik proportionale random sampling, yaitu ukuran sampling. Jumlah responden dalam penelitian ini adalah jumlah responden yang disarankan sesuai dengan teori Hair yaitu 200. Jumlah sampel untuk masingmasing sekolah diambil secara proporsional sesuai jumlah populasi setiap sekolahnya. Jumlah sampel dapat dilihat pada Tabel 1 .

Berdasarkan penghitungan penyebaran responden terdapat nilai pembulatan, sehingga total responden menjadi 201 responden.

\section{Prosedur}

Tahapan penelitian yang dilaksanakan dalam penelitian ini sesuai dengan tahapan untuk prosedur SEM, yaitu: (1) mendefinisikan konstruk-konstruk secara individuas, dengan cara memilih item atau pertanyaan apa yang digunakan sebagai variabel terukur (indikator); (2) mengembangkan dan merinci model pengukuran, dengan cara membuat variabel terukur (indikator) dengan konstruknya dan menggambarkan diagram jalur untuk persamaan pengukuran; (3) merancang suatu studi untuk memperoleh hasil secara empiris, dengan cara menilai kecukupan dari ukuran sampel dan memilih metode estimasi; (4) menilai validitas model pengukuran, dengan cara mengestimasi batas goodness of fit dan validitas konstrak dari persamaan pengukuran. Jika persamaan pengukuran tidak valid, maka tahap selanjutnya adalah memperbaiki pengukuran dan merancang suatu studi baru. Jika persamaan pengukuran valid, maka tahap 
Tabel 2. Skor Pengukuran Instrumen

\begin{tabular}{clcc}
\hline No & & Alternatif Jawaban & Skor \\
\hline 1 & sangat tidak perlu & tidak pernah & 1 \\
2 & tidak perlu & hampir tidak pernah & 2 \\
3 & cukup perlu & kadang-kadang & 3 \\
4 & perlu & hampir selalu & 4 \\
5 & sangat perlu & selalu & 5 \\
\hline
\end{tabular}

selanjutnya adalah meneruskan uji persamaan struktural dengan tahap 5 dan 6; (5) menentukan model struktural, dengan cara merubah atau menggabungkan persamaan pengukuran ke persamaan struktural; dan (6) menilai validitas model struktural, dengan cara mengestimasi goodness of fit dan signifikansi, arah, dan ukuran estimasi parameter struktural. Jika persamaan struktural tidak valid, maka tahap selanjutnya adalah memperbaiki persamaan dan menguji dengan data baru. Jika persamaan struktural valid, maka tahap selanjutnya adalah menggambarkan kesimpulan dan rekomendasi sesungguhnya. (Hair, 2010, pp.588-609).

\section{Intrumen dan Teknik Pengumpulan Data}

Teknik pengumpulan data adalah dengan menggunakan kuesioner. Kuesioner terdiri dari 3 bagian yakni identitas responden, petunjuk pengisian, serta item pertanyaan terstruktur yang mewakili indikator variabel peran kepala sekolah. Untuk memperoleh data yang obyektif, responden tidak diminta untuk mencantumkan nama.

Kuesioner dikembangkan dari dimensi mengenai varibel peran kepala SMK yang dituangkan pada indikator-indikator. Dari indikator-indikator tersebut disusun butirbutir pertanyaan dengan jawaban yang telah disediakan. Guru diminta untuk memberikan pendapat mengenai kompetensi peran kepala SMK yang ideal, apakah peran tersebut perlu atau tidak perlu untuk dijalankan dengan 5 pilihan jawaban, yaitu sangat tidak perlu, tidak perlu, cukup perlu, perlu, dan sangat perlu. Selain memberikan pendapat mengenai peran kepala SMK yang ideal, guru juga diminta memberikan penilaian terhadap peran kepala SMK dengan 5 pilihan jawaban yaitu tidak pernah, hampir tidak pernah, kadang-kadang, hampir selalu, dan selalu.
Skala pengukuran setiap alternatif jawaban menggunakan skala likert. Untuk keperluan analisis kuantitatif maka jawaban diberi skor yang dapat dilihat pada Tabel 2.

\section{Teknik Analisis Data}

Penelitian ini menggunakan teknik Structural Equation Modelling (SEM) dengan pendekatan analisis faktor konfirmatori (confirmatory factor analisys, CFA). Penelitian ini menggunakan perangkat lunak Microsoft Excel 2010, Lisrel 8.54 dan IBM SPSS Statstic 20 untuk menganalisis data yang diperoleh dari lapangan. Perhitungan sederhana dilakukan dengan excel agar selanjutnya data dapat dibaca oleh Lisrel 8.54 dan IBM SPSS Statistic 20. Selanjutnya uji persyaratan analisis multivariat dilakukan dengan IBM SPSS Statistic 20. Analisis faktor konfirmatori dilakukan dengan menggunakan Lisrel 8.54.

Setelah ditentukan model peran kepala sekolah yang sesuai, selanjutnya dilakukan analisis data mengenai peran kepala sekolah itu sendiri. Analisis ini menggunakan statistik deskriptif. Untuk melihat kagegorisasi pencapaian peran kepala sekolah, data penilaian yang sudah diubah menjadi nilai kuantitatif, diubah menjadi nilai kualitatif.

\section{HASIL PENELITIAN DAN PEMBAHASAN}

Kepala sekolah merupakan pemimpin suatu sekolah dimana diselenggarakan proses belajar mengajar atau tempat di mana terjadi interaksi antara guru yang memberi pelajaran dan murid yang menerima pelajaran. Keterampilan kepala sekolah sangat berdampak pada kualitas sekolah. Untuk itu, dalam menjalankan tugasnya, kepala sekolah harus melaksanakan perannya dengan baik. 
Tabel 3. Ringkasan nilai cut off goodness of fit

\begin{tabular}{clll}
\hline No & Jenis Kriteria & Kriteria & Nilai Cut Off \\
\hline 1 & Absolute Fit Indices & Chi-Square & $\mathrm{P} \geq 0,050$ \\
& & Goodness of Fit Index (GFI) & $>0,90$ \\
& & Root Mean Square Error of & $0,05-0,08$ \\
& & Approximation (RMSEA) & \\
2 & Incremental Fit & Adjusted Goodness of Fit (AGFI) & $\geq 0,90$ \\
& Indices & Normed Fit Index (NFI) & $>0,90$ \\
& & Comparative Fit Index (CFI) & $>0,90$ \\
& & Incremental Fit Index (IFI) & $>0,90$ \\
& & Relative Fit Indices (RFI) & $>0,90$ \\
3 & Persimonious Fit & Akaike's Information Criterion (AIC) & $<$ AIC Saturated dan \\
& Indices & & Independence Model \\
& & Expected Cross Validation Index (ECVI) & $<$ ECFI Saturated dan \\
& & & Independence Model \\
& & & $>0,60$ \\
\hline
\end{tabular}

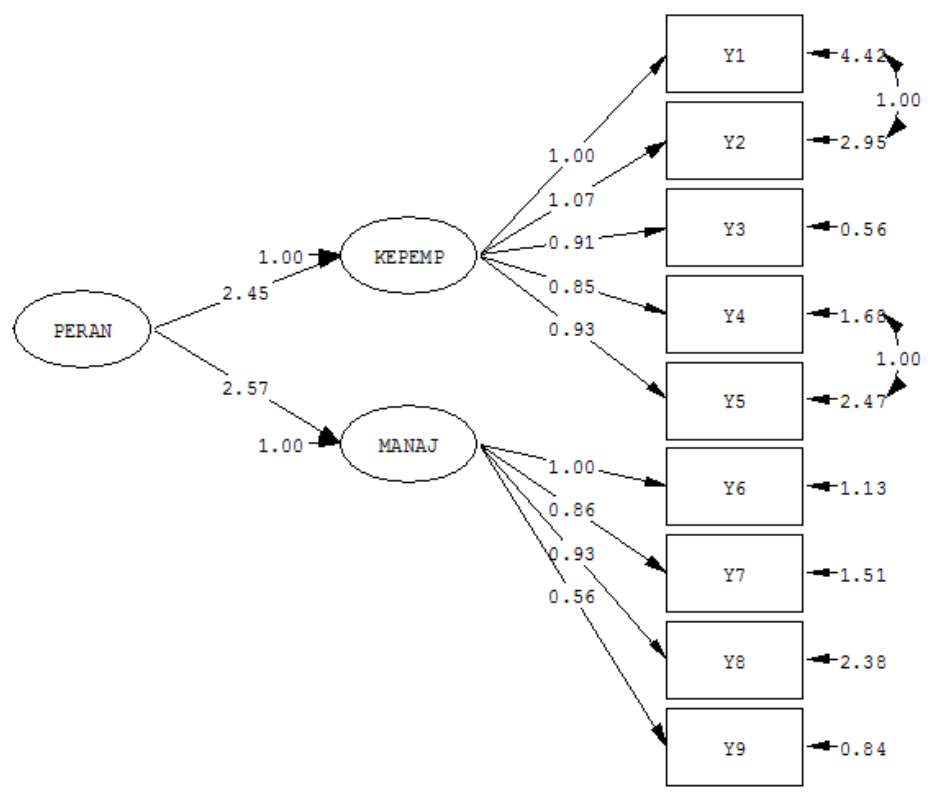

Gambar 1. Hasil Pengujian Konstruk Peran Kepala Sekolah

Adapun peran kepala sekolah dibagi menjadi 2 peran utama, yakni (1) kepala sekolah sebagai pemimpin dan (2) kepala sekolah sebagai manajer. Masing-masing peran tersebut memiliki indikator pencapaiannya.

Peran kepala sekolah sebagai pemimpin dinilai dari(1)kecakapan pribadi,(2) kecakapan relasional, (3) kecakapan profesional, (4) kecakapan berorganisasi, dan (5) kecakapan wirausaha. Sedangkan kepala sekolah sebagai manajer dinilai dari (1) perencanaan, (2) pengorganisasian, (3) penggerakan, dan (4) pengendalian.

\section{Pengujian Model}

Model struktural peran kepala sekolah yang diuji dengan melihat pada dimensi kepemimpinan dan manajerial. Masing-masing dimensi tersebut mempunyai indikator yang terukur (observed). Pengujian model dilakukan 
Tabel 4. Hasil Pengujian Konstruk Model

\begin{tabular}{|c|c|c|c|c|c|}
\hline No & Jenis Kriteria & Kriteria & Nilai Cut Off & $\begin{array}{l}\text { Hasil } \\
\text { Pengujian }\end{array}$ & Keterangan \\
\hline \multirow[t]{3}{*}{1} & \multirow[t]{3}{*}{$\begin{array}{l}\text { Absolute Fit } \\
\text { Indices }\end{array}$} & Chi-Square & $P \geq 0,050$ & $\begin{array}{l}49,55 \\
(p<0,050)\end{array}$ & $\begin{array}{l}\text { Tidak } \\
\text { Memenuhi }\end{array}$ \\
\hline & & $\begin{array}{l}\text { Goodness of Fit Index } \\
\text { (GFI) }\end{array}$ & $>0,90$ & 0,92 & Memenuhi \\
\hline & & $\begin{array}{l}\text { Root Mean Square } \\
\text { Error of Approximation } \\
\text { (RMSEA) }\end{array}$ & $0,05-0,08$ & 0,065 & Memenuhi \\
\hline \multirow[t]{5}{*}{2} & \multirow[t]{5}{*}{$\begin{array}{l}\text { Incremental Fit } \\
\text { Indices }\end{array}$} & $\begin{array}{l}\text { Adjusted Goodness of } \\
\text { Fit (AGFI) }\end{array}$ & $\geq 0,90$ & 0,86 & $\begin{array}{l}\text { Tidak } \\
\text { Memenuhi }\end{array}$ \\
\hline & & Normed Fit Index (NFI) & $>0,90$ & 0,98 & Memenuhi \\
\hline & & $\begin{array}{l}\text { Comparative Fit Index } \\
\text { (CFI) }\end{array}$ & $>0,90$ & 0,98 & Memenuhi \\
\hline & & $\begin{array}{l}\text { Incremental Fit Index } \\
\text { (IFI) }\end{array}$ & $>0,90$ & 0,98 & Memenuhi \\
\hline & & $\begin{array}{l}\text { Relative Fit Indices } \\
\text { (RFI) }\end{array}$ & $>0,90$ & 0,97 & Memenuhi \\
\hline \multirow[t]{3}{*}{3} & \multirow[t]{3}{*}{$\begin{array}{l}\text { Persimonious } \\
\text { Fit Indices }\end{array}$} & $\begin{array}{l}\text { Akaike's Information } \\
\text { Criterion (AIC) }\end{array}$ & $\begin{array}{l}<\text { AIC Saturated } \\
\text { dan Independence } \\
\text { Model }\end{array}$ & $\begin{array}{l}85,55<90,00 \\
\text { dan } 3834,66\end{array}$ & Memenuhi \\
\hline & & $\begin{array}{l}\text { Expected Cross } \\
\text { Validation Index (ECVI) }\end{array}$ & $\begin{array}{l}<\text { ECFI Saturated } \\
\text { dan Independence } \\
\text { Model }\end{array}$ & $\begin{array}{l}0,43<0,46 \\
\text { dan } 19,27\end{array}$ & Memenuhi \\
\hline & & $\begin{array}{l}\text { Parsimonious Goodness } \\
\text { of Fit Index (PGFI) }\end{array}$ & $>0,60$ & 0,55 & $\begin{array}{l}\text { Tidak } \\
\text { Memenuhi }\end{array}$ \\
\hline
\end{tabular}

dengan menilai goodness of fit model. Apabila goodness of fit yang dihasilkan suatu model itu baik, maka model tersebut dapat diterima dan sebaliknya jika goodness of fit model itu buruk maka model tersebut harus ditolak. Secara keseluruhan terdapat tiga jenis ukuran goodness of fit yaitu (1) absolute fit indices; (2) incremental fit indices; dan (3) parsimony fit indices. Dalam penelitian peneliti tidak dituntut untuk memenuhi semua kriteria goodness of fit. 4 - 5 kriteria sudah cukup untuk menilai kelayakan model asal masing-masing kriteria absolute fit indices, incremental fit indices dan parsimony fit indices terwakili (Latan, 2012, p.49; Hair et al., 2010, p.604). Berikut ini ringkasan nilai cut off goodness of fit (Latan, 2012, pp.49-53). (Tabel 3)

Diagram jalur pengujian model konstruk peran kepala sekolah ditunjukkan dalam gambar 1. Pengujian dilakukan dengan menggunakan beberapa estimasi yang diinputkan dalam sintak SIMPLIS aplikasi LISREL. Adapun hasil pengujian secara ringkas dapat dilihat pada tabel 4 .

Berdasarkan hasil pengujian, Goodness of Fit Index (GFI), Root Mean Square Error of Approximation (RMSEA), Normed Fit Index (NFI), Comparative Fit Index (CFI), Incremental Fit Index (IFI), Relative Fit Indices (RFI), Akaike's Information Criterion (AIC) dan Expected Cross Validation Index (ECVI) memenuhi kriteria goodness of fit model. Sedangkan Chi-Square, Adjusted Goodness of Fit (AGFI) dan Parsimonious Goodness of Fit Index (PGFI) tidak memenuhi kriteria goodness of fit model. Namun, sesuai dengan teori yang telah disampaikan sebelumnya bahwa tidak semua kriteria goodness of fit harus terpenuhi asalkan masing-masing kriteria absolute fit indices, incremental fit indices dan parsimony 
fit indices terwakili, maka model konstruk peran kepala sekolah yang dihipotesiskan dalam penelitian ini dapat diterima. Hal ini didukung dengan koefisien jalur dari semua dimensi dan muatan faktor $(\gamma)$ dari semua indikator $(\lambda)$ yang cukup tinggi, bernilai positif dan signifikan $(\mathrm{p}<0,050)$. Koefisien determinan (R2) dari indikator terhadap dimensi yang terendah adalah 0,61 (koefisien determinan indikator kecakapan pribadi terhadap kepemimpinan) dan tertinggi adalah 0,91 (koefisien determinan indikator kecakapan profesional terhadap kepemimpinan). Koefisien determinan dari dimensi terhadap variabel yang terkecil adalah 0,86 dimiliki oleh dimensi kepemimpinan dan yang tertinggi 0,87 dimiliki dimensi menajerial.

Persamaan pengukuran yang diperoleh gambar 1 dalam bentuk matriks adalah sebagai berikut:

$$
\left[\begin{array}{l}
\mathrm{Y} 1 \\
\mathrm{Y} 2 \\
\mathrm{Y} 3 \\
\mathrm{Y} 4 \\
\mathrm{Y} 5 \\
\mathrm{Y} 6 \\
\mathrm{Y} 7 \\
\mathrm{Y} 8 \\
\mathrm{Y} 9
\end{array}\right]=\left[\begin{array}{ll}
1,00 & 0 \\
1,07 & 0 \\
0,91 & 0 \\
0,85 & 0 \\
0,93 & 0 \\
0 & 1,00 \\
0 & 0,86 \\
0 & 0,93 \\
0 & 0,56
\end{array}\right]\left[\begin{array}{l}
\text { Kepemp } \\
\text { manaj }
\end{array}\right]+\left[\begin{array}{l}
4,42 \\
2,95 \\
0,56 \\
1,86 \\
2,46 \\
1,13 \\
1,51 \\
2,38 \\
0,84
\end{array}\right]
$$

Bila diubah dalam bentuk aljabar biasa, persamaan pengukuran Gambar 1 adalah sebagai berikut:

$$
\begin{aligned}
\mathrm{Y} 1 & =\text { Kepemp }+4,42 \\
\mathrm{Y} 2 & =\text { Kepemp }+2,95 \\
\mathrm{Y} 3 & =\text { Kepemp }+0,56 \\
\mathrm{Y} 4 & =\text { Kepemp }+1,86 \\
\mathrm{Y} 5 & =\text { Kepemp }+2,47 \\
\mathrm{Y} 6 & =\text { Manaj }+1,13 \\
\mathrm{Y} 7 & =\text { Manaj }+1,51 \\
\mathrm{Y} 8 & =\text { Manaj }+2,38 \\
\mathrm{Y} 9 & =\text { Manaj }+0,84
\end{aligned}
$$

Reliabilitas konstruk (construct validity) $=(\Sigma \text { muatan faktor })^{2} /(\Sigma \text { muatan faktor })^{2}+$ ( $\Sigma$ kesalahan pengukuran), sedangkan varian terekstrak (variance extracted $)=\Sigma$ muatan faktor $^{2} /\left(\Sigma\right.$ muatan faktor ${ }^{2}+(\Sigma$ kesalahan pengukuran) (Hair et al., 2010, pp.639).
Berdasarkan pengukuran maka reliabilitas konstruk peran kepala sekolah adalah 0,784 sedangkan varians terekstrak dari persaamaan pengukuran adalah 0,292.

Persamaan struktural yang diperoleh dari gambar 1 dalam bentuk matriks adalah sebagai berikut:

$$
\left[\begin{array}{l}
\text { kepemp } \\
\text { manaj }
\end{array}\right]=\left[\begin{array}{l}
2,45 \\
2,57
\end{array}\right][\text { perang }]+\left[\begin{array}{l}
1,00 \\
1,00
\end{array}\right]
$$

Persamaan struktural gambar 1 dalam bentuk persamaan aljabar biasa adalah sebagai berikut:

$$
\begin{array}{ll}
\text { Kepemp } & =2,45 \text { Peran }+1,00 \\
\text { Manaj } & =2,57 \text { Peran }+1,00
\end{array}
$$

Garis-garis lengkung antarkonstruk dengan anak panah pada setiap ujungnya menunjukkan korelasi antar konstruk tanpa adanya hubungan sebab akibat. Gambar 1 menunjukkan adanya korelasi antara Y1(kecakapan pribadi) dan Y2(kecakapan relasional) serta Y4(kecakapan berorganisasi) dan Y5(kecakapan wirausaha).

Pengujian model menunjukkan bahwa kepemimpinan dan manajerial merupakan dimensi dari peran kepala sekolah. Kepemimpinan mempunyai 5 indikator yaitu (a) kecakapan pribadi, (b) kecakapan relasional, (c) kecakapan profesional, (d) kecakapan berorganisasi, dan (e) kecakapan wirausaha. Manajerial mempunyai 4 indikator yaitu (a) perencanaan, (b) pengorganisasian, (c) penggerakan, dan (d) pengendalian. Begitu juga dengan indikator-indikator yang terkandung dalam semua dimensi menunjukkan hasil baik. Itu berarti kesahihan data pada penelitian ini menunjukkan hasil yang baik sehingga dapat dilakukan interpretasi lebih lanjut.

\section{Peran Kepala SMK di Kota Yogyakarta Berdasar Persepsi Guru}

Peran Kepala SMK di Kota Yogyakarta dapat dilihat melalui kesesuaian antara kondisi riil peran kepala sekolah dengan kondisi idealnya. Perbandingan ini dapat dilihat melalui perbandingan rata-rata (compare means). Berdasarkan uji $\mathrm{F}$ diketahui bahwa varians data kondisi riil dan kondisi ideal adalah tidak sama. Uji t menunjukkan hasil bahwa rata-rata (mean) kondisi riil berbeda dengan kondisi 


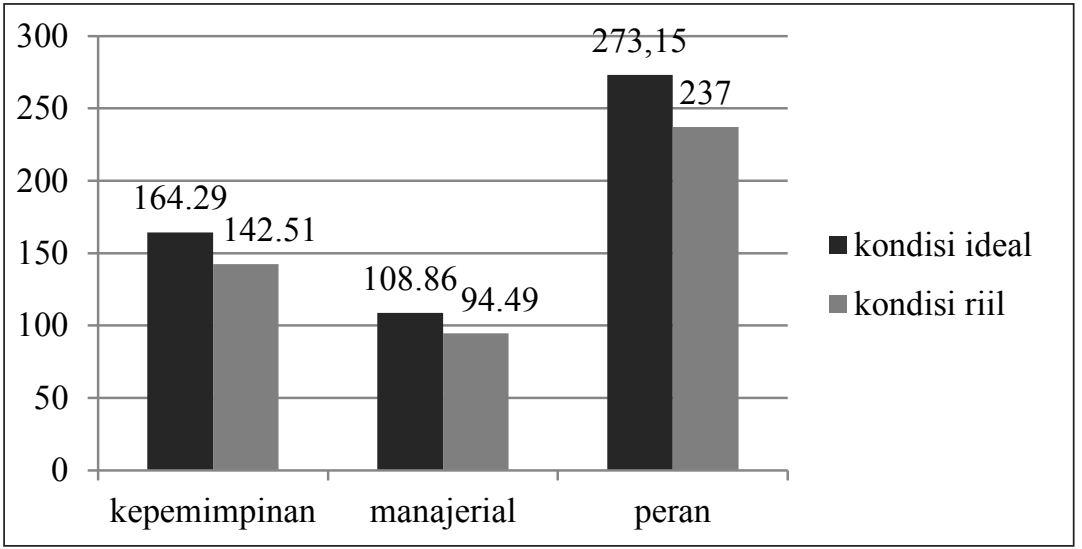

Gambar 2. Perbandingan Kondisi Ideal dan Kondisi Riil Peran Kepala Sekolah

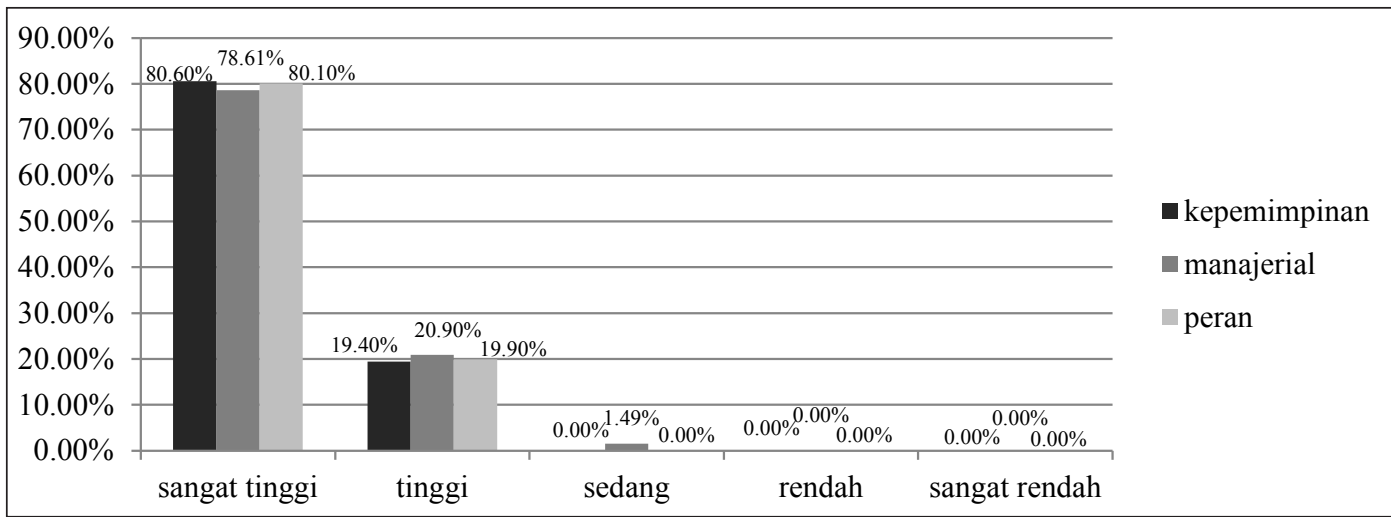

Gambar 3. Grafik Kondisi Ideal Peran Kepala Sekolah Menurut Guru

ideal, dalam artian kondisi riil memiliki ratarata lebih rendah dibanding kondisi ideal. Setelah dilakukan uji $\mathrm{F}$ dan uji $\mathrm{t}$ dan diketahui ada perbedaan yang nyata antara kondisi riil dan kondisi ideal, langkah selanjutnya adalah mengetahui seberapa besar perbedaan tersebut. Perbedaan rata-rata (mean difference) antara kondisi riil dengan kondisi ideal adalah 36,149.

Penilaian kondisi ideal peran kepala sekolah berdasar persepsi guru menunjukkan bahwa $80,10 \%$ guru memberikan nilai sangat tinggi, $19,90 \%$ guru memberikan nilai tinggi, $0 \%$ memberikan nilai sedang, $0 \%$ memberikan nilai rendah, dan $0 \%$ memberikan nilai sangat rendah. Secara lebih rinci, pada dimensi kepemimpinan $80,60 \%$ guru memberikan nilai sangat tinggi, $19,40 \%$ guru memberikan nilai tinggi, $0 \%$ mamberikan nilai sedang, $0 \%$ memberikan nilai rendah dan $0 \%$ memberikan nilai sangat rendah. Sedangkan pada dimensi manajerial $78,61 \%$ guru memberikan nilai sangat tinggi, $20,90 \%$ memberikan nilai tinggi, $1,49 \%$ memberikan nilai sedang, $0 \%$ memberikan nilai rendah dan $0 \%$ memberikan nilai sangat rendah.

Penilaian kondisi riil peran kepala sekolah berdasar persepsi guru menunjukkan bahwa $28,36 \%$ guru memberikan nilai sangat tinggi, $59,20 \%$ guru memberikan nilai tinggi, $11,44 \%$ memberikan nilai sedang, 1,00\% memberikan nilai rendah, dan $0 \%$ memberikan nilai sangat rendah. Secara lebih rinci, pada dimensi kepemimpinan $30,85 \%$ guru memberikan nilai sangat tinggi, $57,21 \%$ guru memberikan nilai tinggi, $10,95 \%$ memberikan nilai sedang, 1,00\% memberikan nilai rendah dan $0 \%$ memberikan nilai sangat rendah. Sedangkan pada dimensi manajerial $31,34 \%$ guru memberikan nilai sangat tinggi, 53,73\% memberikan nilai tinggi, $12,94 \%$ memberikan nilai sedang, $1,99 \%$ memberikan nilai rendah dan $0 \%$ memberikan nilai sangat rendah. 


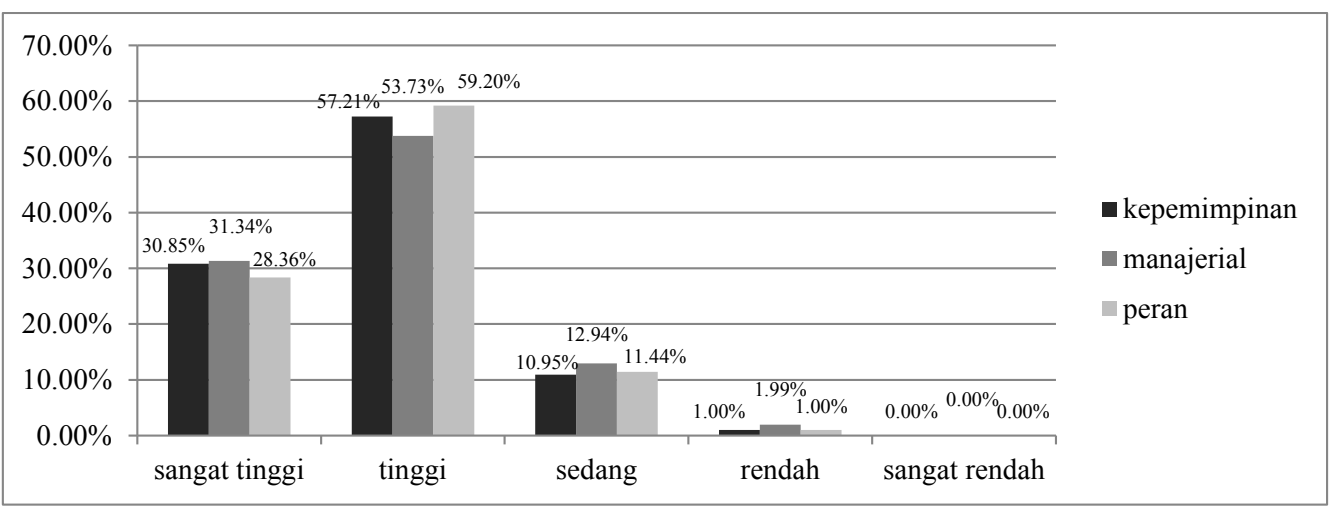

Gambar 4. Grafik Kondisi Riil Peran Kepala Sekolah Menurut Guru

\section{SIMPULAN DAN SARAN}

\section{Simpulan}

Berdasarkan analisis hasil dan pembahasan pada bab sebelumnya, maka dapat ditarik simpulan sebagai berikut : (1) Model konstruk peran kepala SMK memiliki 2 dimensi, yaitu dimensi kepemimpinan dan dimensi manajerial. Kepemimpinan mempunyai 5 indikator, yaitu (a) kecakapan pribadi, (b) kecakapan relasional, (c) kecakapan profesional, (d) kecakapan berorganisasi, dan (e) kecakapan wirausaha. Manajerial mempunyai 4 indikator, yaitu (a) perencanaan, (b) pengorganisasian, (c) penggerakan, dan (d) pengendalian; dan (2) Kondisi riil peran kepala sekolah hampir sesuai dengan kondisi idealnya, ditunjukkan dengan mean kondisi riil yang sedikit lebih rendah dari mean kondisi ideal. Secara rinci kondisi riil peran kepala sekolah berdasar persepsi guru menunjukkan bahwa $28,36 \%$ guru memberikan nilai sangat tinggi, 59,20\% guru memberikan nilai tinggi, $11,44 \%$ memberikan nilai sedang, 1,00\% memberikan nilai rendah, dan $0 \%$ memberikan nilai sangat rendah.

\section{Saran}

Berdasarkan simpulan dan implikasi di atas, maka diajukan saran-saran sebagai berikut: (1) Upaya peningkatan kualitas kepala sekolah, seperti penyelenggaraan kegiatankegiatan seminar maupun pelatihan (training) bagi kepala sekolah sebaiknya disesuaikan dengan teori peran kepala sekolah sehingga hasil yang dicapai akan maksimal. Selain itu, perkembangan peran kepala sekolah juga harus terus dipantau dan dievaluasi; dan (2) Kepala sekolah hendaknya menyadari peran pentingnya sebagai kunci keberhasilan sekolah. Untuk itu, kepala sekolah perlu meningkatkan motivasi untuk berperan dengan lebih baik lagi serta berupaya untuk meningkatkan kualitasnya, misalnya dengan mengikuti pelatihan (training). Selain itu, kepala sekolah juga harus mampu berpikir strategis dan inovatif dalam menghadapi tuntutan perubahan. Pihak sekolah seperti siswa, guru, dan karyawan diharapkan dapat mendukung kepala sekolah untuk meningkatkan perannya. Kepala sekolah membutuhkan kerjasama yang baik dari seluruh pihak sekolah sehingga dapat meningkatkan keberhasilan sekolah.

\section{DAFTAR PUSTAKA}

Arikuntono, Indra. (7 Juli 2012). Kinerja kepala sekolah dan pengawas harus dikontrol. Diakses pada tanggal 5 Maret 2014, dari http://edukasi.kompas.com/ $\mathrm{read} / 2012 / 07 / 07 / 06500662 /$ Kinerja.Kepala. Sekolah.dan.Pengawas.Harus.Dikontrol

Barnett, K., \& McCormick, J. (2004). Leadership and individual principalteacher relationship in schools. Educational Administration Quarterly, 40(3), 406-434.

Beyer, M. B., \& Ruhl S, C. (1998). The principal's role in school restructuring and reform: An examination of selfperceived leadership styles. The Journal of Leadership Studies, 5(2), 116-128. 
Day, C., \& Harris, A. (1999). Successful leadership for effective school in the $21^{\text {st }}$ century. Management in Education, 13(4), 6-8.

Demir, Kamile. (2008). Transformational leadership and collective efficacy: the moderating roles of collaborative culture and teachers' self-efficacy. Egitim Arastirmalari-Eurasian Journal of Educational Research. 8(33), 93-112.

Edgerson, E. D., \& Kritsonis, A. W. (2006). Analysis of influence of principalteacher relationship on student academic achievement: A national focus. National Journal for Publishing and Mentoring Doctoral Student Research, 1(1), 1-5.

Evans, L. (2001). Delving deeper into morale, job satisfaction and motivation among education professional: Re-examining the leadership dimension. Educational Management \& Administration, 29(3), 291-306.

Hair, J. F., Black, W. J., Babin, B. J., \& Anderson, R. E.. (2010). Multivariate data analysis. Englewood Cliff, NJ: Prentice Hall.

Idhom, A. M.. (12 Desember 2013). Di Yogya, pendidikan termasuk paling bermasalah. Diakses pada tanggal 5 Maret 2014, dari http://www.tempo.co/ $\mathrm{read} / \mathrm{news} / 2013 / 12 / 12 / 079536937 / \mathrm{Di}-$ Yogya-Pendidikan-Termasuk-PalingBermasalah

Kemdikbud. (6 Desember 2013). Kompetensi supervisi kepala sekolah masih perlu ditingkatkan. Diakses pada tanggal 5 Maret 2014, dari http://kemdikbud. go.id/kemdikbud/berita/1430

Latan, H. (2012). Structural equation modelling: Konsep dan aplikasi menggunakan program Lisrel 8.8 . Bandung: Alfabeta.
Neni. (5 Agustus 2010). 20 Sekolah di DIY dilaporkan langgarpasaltipikor.Diakses pada tanggal 5 Maret 2014, dari www. republika.co.id/berita/breaking-news/ nusantara/10/08/05/128291-20-sekolahdi-diy-dilaporkan-langgar-pasal-tipikor

Presiden Republik Indonesia. Peraturan Pemerintah Republik Indonesia Nomor 29, Tahun 1990, tentang Pendidikan Menengah.

Presiden Republik Indonesia. Peraturan Pemerintah Republik Indonesia Nomor 17, Tahun 2010, tentang Pengelolaan dan Penyelenggaraan Pendidikan.

Rice, K. J. (2010). Principal effectiveness and leadership in era of accountability: What research says. The Urban Institute, 8, 1-6.

Sekda Kota Jogja lantik 9 kepala SMKSMA. (8 Desember 2007). Diakses pada tanggal 5 Maret 2014, dari www. jogjakota.go.id/news/sekda-kota-jogjalantik-9-kepala-smk-sma

Sidik. (14 Februari 2013). Rerata penyerapan tenaga kerja Yogyakarta 12 persen. Diakses pada tanggal 5 Maret 2014, dari www.antarayogya.com/berita/308593/ rerata-penyerapan-tenaga-kerjayogyakarta-12-persen

Wahlstrom, L. K., \& Louis, S. K. (2008). How teachers experience principals leadership: The roles of professional community, trust, efficacy, and shared responsibility. Educational Administration Quarterly, 44(4), 458495. 